\title{
CHRNA3 Gene
}

National Cancer Institute

\section{Source}

National Cancer Institute. CHRNA3 Gene. NCI Thesaurus. Code C77118.

This gene plays a role in the regulation of ion transport. 